\title{
The Flotation Process Can Go Green
}

\author{
George Z. Kyzas ${ }^{1, *(1)}$ and Kostas A. Matis ${ }^{2, *(1)}$ \\ 1 Hephaestus Advanced Laboratory, Eastern Macedonia and Thrace Institute of Technology, \\ 65404 Kavala, Greece \\ 2 Division of Chemical Technology \& Industrial Chemistry, Department of Chemistry, Aristotle University of \\ Thessaloniki, 54124 Thessaloniki, Greece \\ * Correspondence: kyzas@teiemt.gr (G.Z.K.); kamatis@chem.auth.gr (K.A.M.); Tel.: +30-2510-462247 (G.Z.K.)
}

Received: 14 February 2019; Accepted: 2 March 2019; Published: 6 March 2019

\begin{abstract}
In today's world of environmental strain, wastewater treatment has become a, more or less, conventional application of flotation - as for instance, in the oil, food, or chemical industries, and in potable water treatment. In this paper, different flotation methods (such as ion, adsorbing colloid, and adsorptive flotation, including biosorption) and techniques will be reviewed; and, in order to explain them further, several applications of these from the laboratory (General and Inorganic Chemical Technology) at Aristotle University of Thessaloniki, Greece (AUTh) will be presented and analyzed, with the main focus on sustainability. The application of flotation as a separation process, when applied in pollution control or during water treatment, was often criticized due to the possible toxicity of the applied collectors; however, the use of biosurfactants may alleviate this concern and enhance its further acceptability.
\end{abstract}

Keywords: floatation; green approach; wastewater treatment; adsorptive floatation; biosurfactants

\section{Introduction}

One of the most unique separation techniques is considered to be flotation, which combines three phases: Gas phase, liquid phase, and solid phase (separately). Flotation has direct application to (or we can say that it originates from) mineral processing, which is called "froth flotation". The latter field presents for sure special peculiarities compared to flotation techniques applied to wastewater treatment [1-5]. Haynes started the systematic application of flotation for sulfides in mineral beneficiation in order to efficiently separate them (with the use of oil) from gangue. In 1905 (Broken Hill, Australia), the first attempt to apply a froth flotation apparatus was recorded, where the intense stirring of the pulp produced air bubbles [6]. However, in the 5th century B.C. in ancient Greece, Herodotus (in Historiae, Book IV) was probably the first person to describe a process similar to flotation. This process was created in order to separate (using fatty substances) gold particles from sand [7]. Quite early also, application of this technique to wastewater treatment was reported [8].

According to the technique used for the generation of gas (usually air) bubbles, which are the transport medium of this separation process, two broad categories of flotation are generally distinguished: Dispersed-air and dissolved-air flotation; these bubble generation methods were extensively studied and compared [9]. The potential for sustainability in water separation techniques and the applications to "heavy" chemical industry have also been analyzed [10]; it is mandatory worldwide to find methods for obtaining new / fresh sources of drinking water. It has been said there are several major gains in the understanding, insight, capability, and efficiency that come from viewing the separation processes as a unified field [11].

A new surfactant (seed oil from a tree) was evaluated for deinking flotation [12]; deinking before the recycling of paper is a demanding process from an environmental standpoint. Recycling printed circuit boards using suitable technology (here, by inverse flotation) is increasingly important due to 
the metals these contain and the environmental care that must be taken when separating the different materials [13]. The contact angle measurement allows the determination of whether flotation would occur or not (and thus establishes a material as hydrophobic or not). The potential of an enhanced flotation separation process combined with natural-based green chemicals was determined for wastewater treatment and resource recovery [14]. Betacyanin (which has applications in food processing) extraction was accomplished from the peel and flesh of pitaya using a new integration process, based on the so-called liquid biphasic flotation [15]. Controlling the reaction kinetics gave rise to enhanced separation efficiencies of lanthanides, with the aid of selective density-based flotation [16]. A green flotation method for the separation of small amounts of boron from aqueous solution was published [17].

Hence, the aforementioned selected examples from the literature perhaps already indicate that flotation can go green. Flotation is, in principle, a surfactant-based separation process, where the surfactants are usually termed collectors. Ion flotation is generally a method that involves the removal of surface inactive ions from an aqueous solution by adding the proper surfactant; as a result, a scum appears on the surface of the solution, consisting of solids and containing the surfactant, usually as a chemical constituent, after the passage of gas bubbles through the solution. An evolution of ion flotation (i.e., precipitate flotation) involves the initial formation of some kind of precipitate from the ionic species and the subsequent removal of this. There is also a similar idea involving the removal of a solute by adsorption on or co-precipitation with a carrier floc (which is then floated after the addition usually of a surfactant), termed adsorbing colloid flotation that belongs in general in the group of adsorptive flotation techniques $[18,19]$. Furthermore, the relative costs of the process have been recently examined [20].

Surfactants are considered to be compounds with surface-active potential, which are able to reduce the interfacial (and surficial) tension at the border (interface) interfaces between the liquid-solid-gas phases; therefore, it is allowed to easily disperse or mix resulting in emulsions in water or other liquids. The demand in the market for surfactants is widely known, and, therefore, there are a huge variety of synthetic (majorly having as basis petroleum) and chemical surfactants. The disadvantage is that these molecules (or generally compounds) are toxic and hazardous to environmental life. Additionally, most of them are not biodegradable, and as a result, they may bioaccumulate, whereas their production processes and byproducts can be environmentally hazardous.

\section{Mineral Processing}

Chitosan is a polymer, which was tested for potential selectivity as a green depressant of pyrite in the bulk flotation of galena and chalcopyrite from sphalerite and pyrite-using a xanthate (dithiocarbonate) as a collector and methyl isobutyl carbinol (MIBC) as a frother [21]. Earlier, the role of dextrin in the xanthate flotation of pyrite and sphalerite was examined, by means of flotation tests and micro-electrophoretic measurements [22]; the exclusion of hazardous cyanides in mineral processing has been of particular interest. Recently, cellulose was applied as a candidate for a green alternative due to its natural abundance (regarding the polymeric source) and possibly can participate as an antagonist of synthetic chemicals, which are now used; alkylaminated nanocelluloses of linear form were investigated in the selective flotation of aluminum oxide and quartz [23]. Cellulose can be modified in a physical or chemical manner in order to have (obtain) tailored properties. So, it can be employed in the chemical industry and especially in flotation techniques. The Derjaguin-Landau-Verwey-Overbeek theory focused on the forces (or generally the interactions) between cellulose and some minerals by varying the experimental setup [24].

One of the most serious problems is the existence of arsenic in water. This is a big threat to human health in many countries. The problem may be due to the oxidative weathering and dissolution from As-containing minerals of dissolved inorganic arsenic oxyanions, which are transported in the surface or groundwater and can subsequently become adsorbed on soil and sediment particles. Arsenic-rich auriferous pyrite concentrates, often stockpiled in the mine area, could be further enriched in arsenic to also assist Au beneficiation, in case gold is associated with arsenopyrite [25]. Additionally, the potential 
of Eucalyptus oils as green collectors in gold flotation was examined, as xanthates introduce many occupational health and environmental risks that are often overlooked [26]. The density functional theory calculation perhaps opens a new avenue for understanding the reactivity of the groups and atoms in a collector molecule [27].

The mining industry is currently facing significant challenges to identify and adopt sustainable collector chemistries that can effectively recover valued minerals in difficult-to-process low-grade resources. These are typically characterized by complex mineralogy and the presence of significant amounts of penalty gangue sulfide minerals, especially pyrite which is a challenge to separate from valuable minerals at many major mine operations [28]. As it is known, the purpose of mineral processing is, among others, to remove the impurities found in the gangue minerals, as smelters (where the flotation concentrates end) often give penalties based on their level. A deleterious element usually has a specific penalty, which depends on the removal cost (and/or disposal). In other cases, the latter can be varied from the appropriate manner with which we can limit the value of the final metal product [29].

Elsewhere, the flotation behavior of monazite from carbonates was studied [30]. Metals (including molybdenum - mentioned below) are non-renewable resources being consumed at an exponential rate as a result of population and capital growth. Thus, reclamation from industrial solid wastes and wastewaters, especially of the rare or rare-earth metals, is becoming more and more attractive.

\section{Flotation Techniques in Wastewater Treatment}

During the year, the exhaustion of the reserves of metal ores is big, so it is mandatory to recover metals from ores (presenting lower grade). Flotation can be used for even higher concentration and separation. This is even more promising especially in the case of relatively expensive materials in spent or leached dilute solutions. Hydrometallurgy can be traced back only to the end of the 19th century, while pyrometallurgy is admittedly an ancient art of metal production. The former involves two distinct steps: (i) The selective dissolution of metal values from a mineral (raw material), a process known as leaching; and (ii) the selective separation and recovery of these metal values, commonly existing in small concentrations, from the bulk solution.

Arsenic is present usually as an admixture in molybdenum ores, such as molybdenite $\left(\mathrm{MoS}_{2}\right)$. The wastewater generated during the hydrometallurgical treatment of molybdenum minerals usually contains both $\mathrm{As}(\mathrm{V})$ and $\mathrm{Mo}(\mathrm{VI})$ species. Ion flotation was shown to simultaneously float both molybdenum and arsenic anions (in contrast to adsorbing colloid flotation, which was able to separate Mo(VI) from other co-existing anions) (Figure 1).

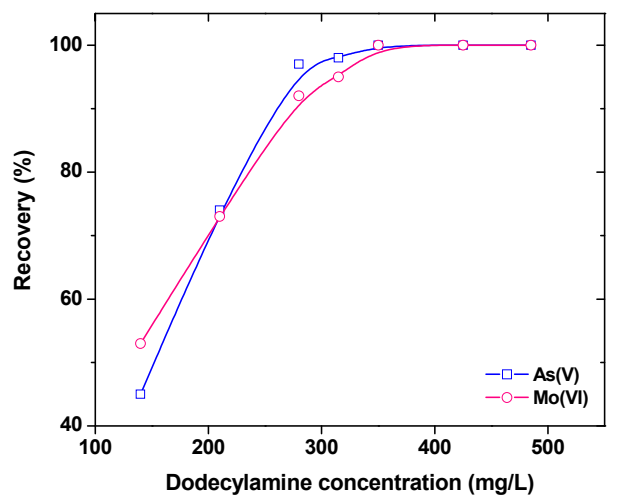

(a)

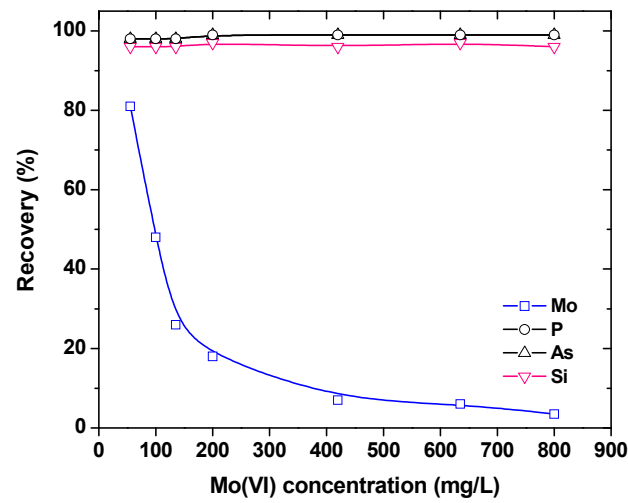

(b)

Figure 1. (a) Ion flotation of an aqueous mixture of arsenic-molydbenum anions by the addition of dodecylamine at $\mathrm{pH}$ 3.6, at different initial concentrations of the collector. Reprinted with permission; copyright Taylor \& Francis [31]. (b) Adsorbing colloid flotation of the separation of molybdate oxyanions from mixtures by dodecylamine at $\mathrm{pH}$ 9: Effect of the initial molybdate concentrations on the selective separation of phosphates, arsenates, and silicates; the latter, as impurities, were initially present in low concentrations. Reprinted with permission; copyright Elsevier [32]. 
A laboratory bench-scale dispersed-air flotation column was applied for this scope; dodecylamine in ethanol solution $(0.5 \% v / v)$ was used as the surfactant for ion flotation. Ferric hydroxide (formed in situ from ferric chloride) was used as the coprecipitant for adsorbing colloid flotation. The aquatic chemistry of the system was also studied [31]. In practical applications, the ion flotation process may be preferred because of its advantages, such as the easy collection of foamate. Therefore, the applied surfactant can be recycled, and arsenic and molybdenum can be recovered.

It was found that by the application of adsorbing colloid flotation over $95 \%$ of impurities, such as $\mathrm{Si}, \mathrm{P}$, and As anions (usually at concentrations of $15 \mathrm{mg} / \mathrm{L}$ each), could be selectively removed from an aqueous solution, also containing molybdate anions at an initial concentration exceeding $200 \mathrm{mg} / \mathrm{L}$; in this case, the simultaneous co-removal (floated) of molybdates was around $20 \%$. The reason for this behavior between the impurities (being floatable) and the molybdates (being mainly non-floatable) is the different solubility between the ferric compounds of molybdates (soluble at the alkaline $\mathrm{pH}$ values) and those of arsenates, phosphates, and silicates, which are present as insoluble precipitates at the applied $\mathrm{pH}$ values; and, hence, they can be easily separated by flotation.

Cadmium-polluted wastewaters come from a large number of industries, which include mainly metal finishing, electroplating, ceramics and inorganic pigments production, metallurgical alloying, zinc smelting, and acid mine drainage. The removal of this priority pollutant is of primary interest to the industries and concerned regulatory agencies, due to its high toxicity. The removal of this toxic metal employing the dissolved-air flotation technique was investigated in laboratory batch experiments; the mechanism of precipitate flotation as the respective hydroxide was followed by sodium dodecyl sulfate (an anionic surfactant), at the $\mathrm{pH}$ range between 10 and 11, approximately [33].

A comparison of three flotation techniques in the hybrid configuration-to be discussed in the following-revealed that precipitate flotation had a better influence on membrane performance [34]; the solution $\mathrm{pH}$ value for the metal removal by precipitation was $\sim 8$ for copper. From a typical thermodynamics investigation (by the MINEQL+ program) for the aqueous chemistry of these metals, it came out that copper precipitates as a hydroxide when the $\mathrm{pH}$ is approaching 6 [35]. Precipitate flotation of copper ions was compared with ion flotation [36].

Figure 2 presents an example for the separation of dissolved germanium species, although it cannot be considered as the typical case of ion flotation. In this application, a specific activator (chemical reagent), such as pyrogallol, should be initially introduced in the original aqueous solution, before accomplishing the effective removal of germanium by the subsequent addition of an appropriate (cationic) surfactant, such as dodecylamine.

The ion flotation method was also applied for the selective separation of germanium from arsenic. A relatively simpler ion flotation system could be (for example) the removal of chromate oxyanions from dilute aqueous solutions by the addition of a cationic surfactant [37].

The reason for the addition above of an activator previously presented (i.e., the respective ion flotation mechanism in this case) was that at low initial aqueous concentrations (i.e., in the range of a few $\mathrm{mg} / \mathrm{L}) \mathrm{Ge}(\mathrm{IV})$ is present at the $\mathrm{pH}$ range of 2-7 in the form of very slightly dissociated meta-germanic acid $\left(\mathrm{H}_{2} \mathrm{GeO}_{3}\right)$, which therefore cannot be directly floated. Pyrogallol is known to form a strongly dissociated complex acid with germanium, having the composition $\mathrm{H}_{2} \mathrm{GeL}_{3}$; hence, in this way it can be subsequently floated (separated) by the addition of a cationic surfactant. The collected foam was found to contain a precipitate with the (analyzed) composition $\mathrm{S}_{2} \mathrm{GeL}_{3}$, where $\mathrm{S}$ is the cation of amine-type surfactant and L represents the complexing ligand (pyrogallol). The stoichiometric mechanism of this separation process was therefore clarified [38].

Several million tons of pulverized fuel ash or fly ash are produced every year from coal burning power plants and collected mainly by using electrostatic precipitators; actually, fly ash is an industrial solid waste, being in some cases almost $20 \%$ of the initial coal weight and may represent serious environmental problems (collection, disposal, etc.). Coal fly ash can be meanwhile considered as an ore already mined, size reduced, and readily available for engineering applications, in substantial quantities and rather consistent composition, depending on the origin and type of burned coal. Only the 
total (if possible) recovery of all the mineral constituents from fly ash, i.e., aluminum, iron, calcium, silicon, sulfur, sodium, titanium, but also (from the trace-contained values), uranium, germanium, molybdenum, etc., is envisioned as economically feasible and will have a positive impact on the ash disposal problem. Some selected preliminary laboratory results were presented on germanium leaching from two different fly ash samples (originated from two Greek power plants, burning lignite of different qualities) by using comparatively dilute solutions of sulfuric acid $(0.5 \% w / v)$ or sodium hydroxide $(0.5 \% w / v)$. The idea was to co-extract and hence, to obtain in the leachate solution as little as possible of the other constituents, so that during the next processing stage (i.e., flotation) possible depression effects [39] could be avoided.

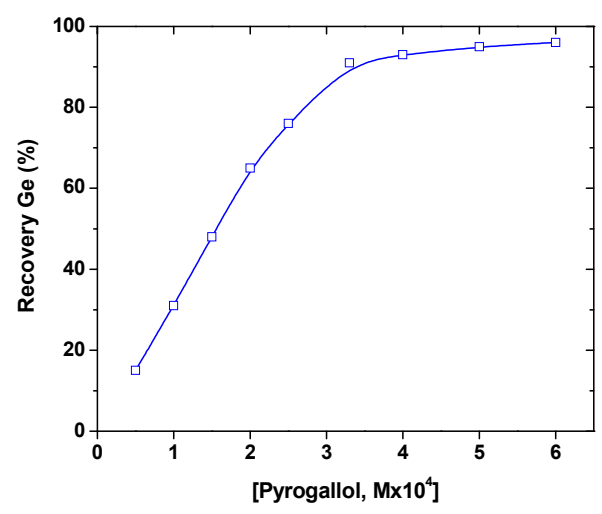

(a)

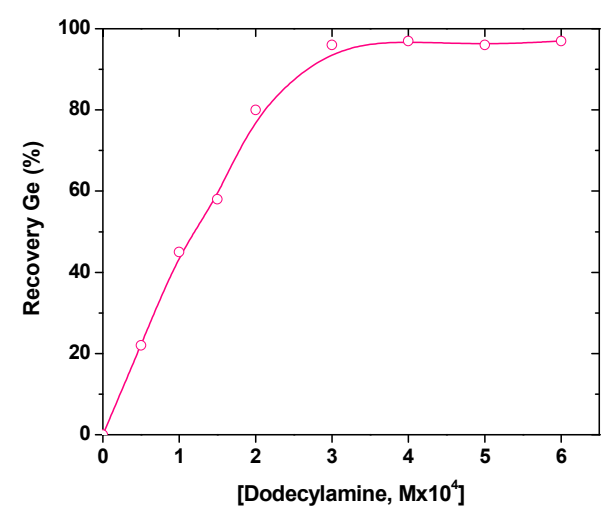

(b)

Figure 2. Ion flotation of germanium from dilute aqueous solutions $\left(1 \times 10^{-4} \mathrm{M}\right.$ initial concentration): (a) Effect of pyrogallol (activator) concentration on germanium ion recovery; dodecylamine concentration kept constant at $2.2 \times 10^{-4} \mathrm{M}$; and (b) varying the concentration of the collector, with 3.3 $\times 10^{-4} \mathrm{M}$ pyrogallol added; effect on recovery and certification of germanium flotation mechanism. Reprinted with permission; copyright Elsevier [38].

Scattered metals play an irreplaceable role in some clean energy technologies and advanced materials, and they will become much more important in the future. During the last decades, hydrometallurgy has continued to present important advances, even replacing some more traditional processes. However, significant amounts of liquid wastes are often produced that may pose serious treatment and disposal problems.

A new approach to recover microalgae from aqueous mediums using a bio-flotation method was reported [40]. Microalgae biomass has great potential for being used as feedstock for the sustainable production of biodiesel, as it is able to produce 7-31 times more oil than the top terrestrial crop; therefore, the foam flotation was studied, since the costs of downstream processing of the dilute biomass are a major challenge for microalgae biodiesel [41]. To improve the harvesting efficiency as well as to reduce the addition of chemicals, positively charged surface-layered polymeric microspheres were prepared [42]. A green water treatment sequence was also developed using a natural coagulant (Moringa oleifera) and a natural activated carbon (vegetable coconut palm) to remove Microcystis aeruginosa and natural organic matter in a flotation-based process [43].

\section{Biosorption Is a Valid Alternative (In Advance, as Pretreatment)}

Adsorption is, by definition, a general term describing the attachment of charged species from a solution to a coexisting solid surface. Reference was given on the use of pyrite and other mineral fines as adsorbents of metal ions [44]. Biosorption can well be another solution in metal ion removal. In general, an adsorbent should be of low cost, require little processing, be abundant in nature, or be a byproduct or waste material from industrial processes.

A huge number of residual biomass tons is fabricated annually from fermentation industries (and from plants with biological wastewater activity); this can be a strong potential source for appropriate 
biosorbents. Hydroxyl, sulfhydryl, carboxyl, and phosphate groups, as well as nitrogen-containing (amino) groups are the major functional groups existing in the surface of the biomass, which are able to interact and generally participate in adsorption or in some cases chelation of some bivalent metal ions. For the latter case, flotation of biological materials was extensively reported and discussed [45].

A multi-stage process was proposed (in collaboration with the Department of Microbiology, Medical School, University of Newcastle-upon-Tyne, UK) and investigated in depth for the removal of aqueous metal ions, at low concentrations, from industrial effluents and other metal-contaminated waters. The process consisted of the following steps:

(i) Contacting biomass of microbial origin with the metal-containing waste stream, so that biosorption of the metal ions can occur; a stirred tank contactor, where the biosorbent was suspended in the liquid, was applied for surface binding.

(ii) Separation by (dispersed-air) flotation of the biomass from the aqueous phase, which can then be discharged. No loss of ultrafine biomass particles was foreseen in this way in contrast to sedimentation.

(iii) Elution of the biosorbed cadmium ions from the biomass, at a high concentration and possibly, the recovery electrochemically in the form of metal (i.e., end product).

(iv) Recycling of biomass and eluant, wherever possible [46].

The effect of the dispersion $\mathrm{pH}$ on heavy metal (noting that an aqueous mixture was tested) removal and biomass recovery is shown in Figure 3a, investigating a winery byproduct ground by a homogenizer into small sizes and fractionated. Sufficient separation (95\%-100\%) was obtained for biomass in the $\mathrm{pH}$ range of 5-9. Zinc and nickel were also removed in the order of $90 \%-95 \%$, but at $\mathrm{pH}$ values higher than 9, where precipitation of these metals can take place. Laboratory-scale multicycle tests followed, consisting of biosorption, flotation, and an elution step at each cycle, before the recycling of the stalk biomass; the biomass floatability was almost quantitative, for all repeated cycles, whereas copper removal was around $95 \%$. The influence of biomass concentration, using a constant dodecylamine (as the collector) concentration $\left(3 \times 10^{-4} \mathrm{~mol} / \mathrm{dm}^{3}\right)$, is given in Figure $3 \mathrm{~b}$. Increasing the biomass concentration resulted in an increasing removal of all metals, due to the availability of more surface-active sites.

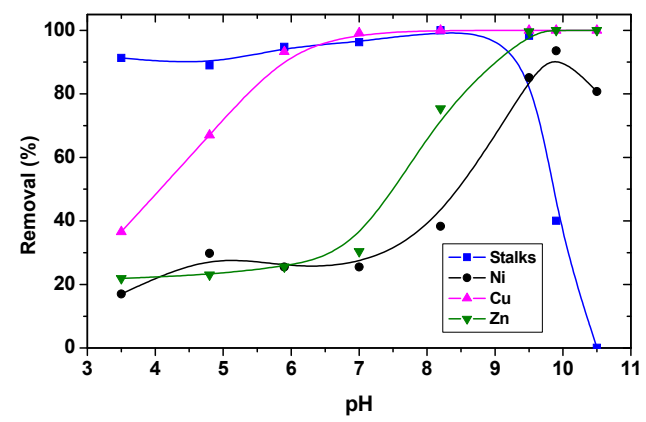

(a)

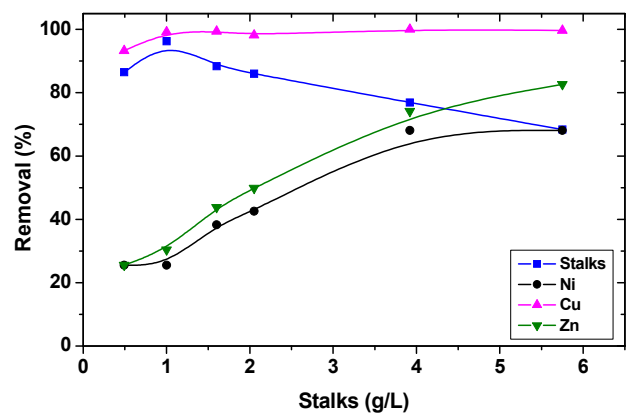

(b)

Figure 3. Use of grape stalks as a biosorbent: (a) Influence of solution $\mathrm{pH}$ on (modified) biomass in the presence of surfactant; and (b) influence of biomass concentration. Reprinted with permission; copyright Wiley [47]. 
So, grape stalks were examined as a biosorbent, for their effectiveness in removing toxic metals from wastewaters, by combining biosorption with flotation in laboratory-scale experiments and then extending the procedure to a pilot scale. The latter experiments consisted of two stages of biosorptive flotation. The polluted aqueous system and the pre-treated biomass were contacted countercurrently. The zeta-potential of the stalks was initially examined for different $\mathrm{pH}$ values of biomass dispersions, in order to obtain more information about the surface charge of this biosorbent [47]. Among the main advantages of using biological materials for the removal of metals is their diversity of active binding sites, which allows their application in various cases. Another advantage of biosorption is that it does not generate the voluminous waste sludges that are typical of the precipitation processes.

\section{Membranes Can Assist}

Electroflotation, where bubbles (basically of hydrogen and oxygen and perhaps chlorine, in the presence of seawater) are generated by electrolysis of the aqueous medium, offers certain advantages over other flotation techniques of bubble generation, i.e., dispersed air or dissolved air. Among others, the following points are perhaps the most important: The electric field gradient between electrodes aids flocculation, the operating conditions can be easily controlled, bypass may be avoided, ionic strength of the effluent solution to be treated is not a crucial parameter, and byproduct recovery is a potentially profitable aspect of the treatment [48]. The two electrodes of the horizontal set, usually applied in electroflotation, could also be separated by a cation exchange membrane, as only one of the previously mentioned gases is usually necessary. In the lower part/separated electrode an electrolyte was circulated to remove the created gas and in the meantime, increase the conductivity. The same idea was applied for mineral processing in a modified Hallimond tube [49].

It was noticed that only one gas (hydrogen) activated the process, when the emulsified oil/water emulsion was studied, while the others acted as depressors or merely contributed to the transfer of the coagulated matter to the flotation cell surface (Figure 4); additionally, an initial demulsification stage was noticed (work conducted at the Chemical Engineering Department, University of Newcastle-upon-Tyne, UK). Meanwhile, when the separation between the gases was applied, an electricity saving was noticed at the laboratory scale. These advances could be achieved on an industrial scale by changing the surface area of the working electrodes, i.e., using electrodes having the shapes of a plate and a rod. It was also observed that the process was capable of operation even without the presence of surfactants-i.e., collectorless. The complete elimination of collector consumption for electroflotation may compensate for the perhaps higher energy requirements, further add to its contribution as a green process.

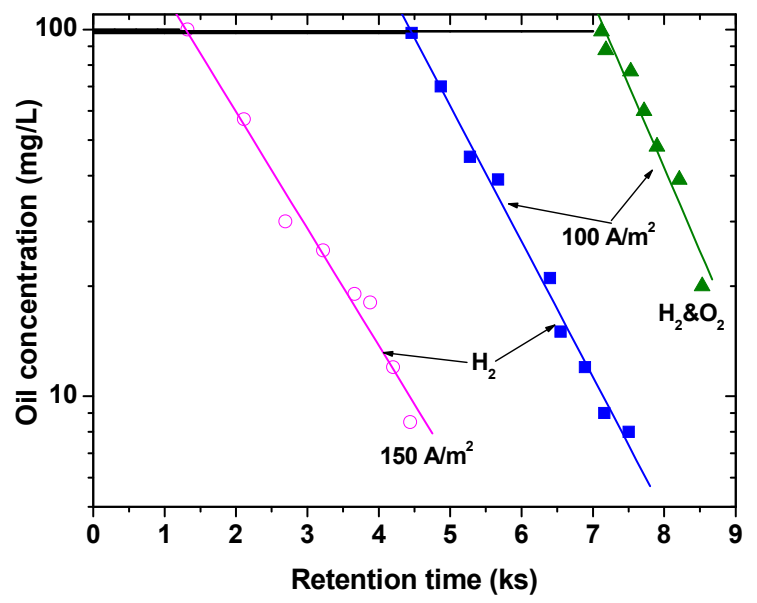

Figure 4. Separating the electrodes, with a membrane (at different current densities): Testing with an oil-water emulsion. Reprinted with permission; copyright Taylor \& Francis [50]. 
A large number of techniques have been used today to limit membrane fouling and among them, certainly, is air bubbling constituting also the transport medium in flotation, as applied in wastewater treatment. Flotation is suitable as a pretreatment stage for microfiltration; ceramic flat-sheet membrane modules of multi-channel geometry were used (United Product Tankers (UPT) GmbH \& Co UPT Ltd., Saarbrücken, Germany).

A gentle backflushing was also required, whose contribution to flotation had no important influence and rather improved the operation. The advantages of both processes, i.e., dispersed-air flotation and microfiltration, were utilized in a hybrid cell. Representative results (Figure 5), concerning the flotation recovery (by cationic surfactants, cetyl-trimethylammonium bromide or cetyl-pyridinium chloride) and zinc removal efficiency are presented; a negative surface charge was observed throughout the examined $\mathrm{pH}$ range, 3-11, in electrokinetic measurements of the brewery yeast. The zinc desorption was almost $100 \%$ using $0.1 \mathrm{M}$ sodium hydroxide, while during the subsequent treatment cycles the brewery yeast could remove $\mathrm{Zn}(\mathrm{II})$ with about the same high effectiveness. A comparison was also carried out with the case of no flotation; so, after $4 \mathrm{~h}$ of operation with the medium air flowrate $(0.447 \mathrm{~cm} / \mathrm{s})$, the trans-membrane pressure was 0.428 bar for the hybrid system, compared with 0.671 bar for microfiltration alone.

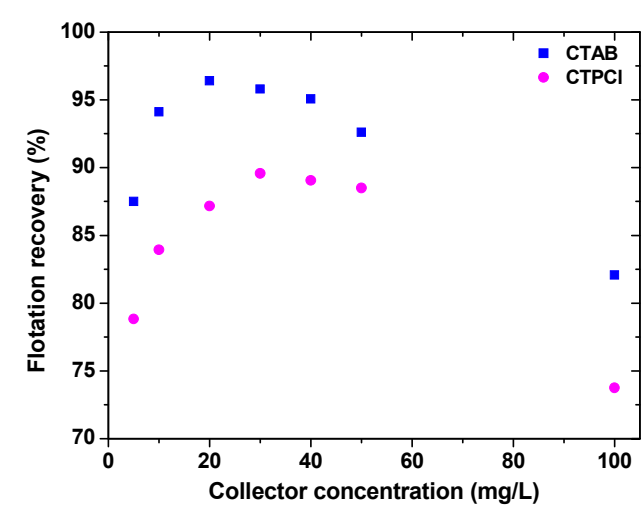

(a)

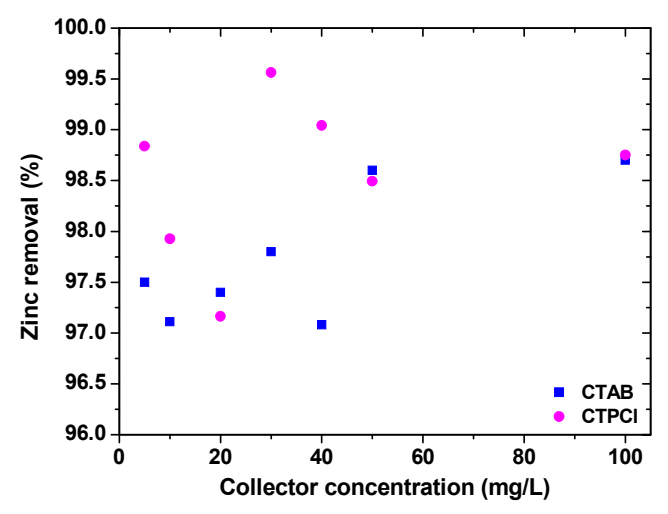

(b)

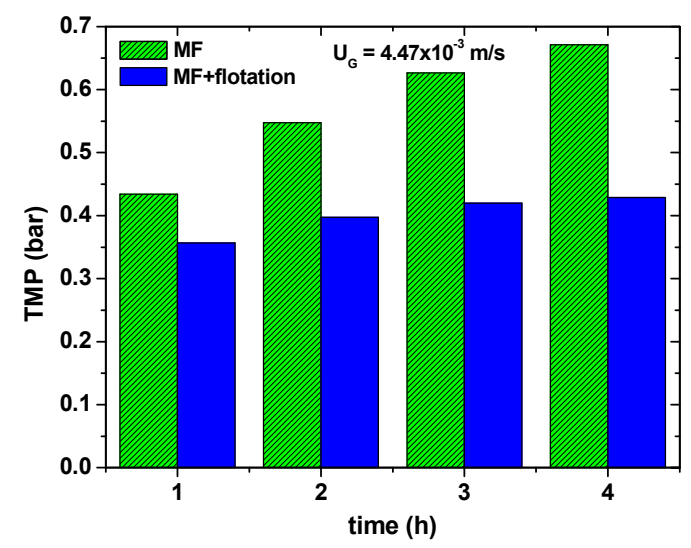

(c)

Figure 5. Batch flotation experiments using a brewery yeast Saccharomyces: (a) Effect of type and concentration of collector on flotation recovery; and $(\mathbf{b})$ removal of zinc ions with $2 \mathrm{~g} / \mathrm{L}$ yeast; $\left[\mathrm{Zn}^{2+}\right]=$ $50 \mathrm{mg} / \mathrm{L}$, [zetag 63] = $2 \mathrm{mg} / \mathrm{L}$, sorption time $=10 \mathrm{~min}$, conditioning time $=10 \mathrm{~min}$, flotation time $=3 \mathrm{~min}$, air flow rate $=160 \mathrm{cc} / \mathrm{min}, \mathrm{pH}=6-6.5$; and (c) improvement of hybrid flotation-microfiltration (MF) system operation as compared with simple MF system with air sparging. Reprinted with permission; copyright Taylor \& Francis [51].

The system investigated earlier was zeolites $\left(\mathrm{Na}_{2} \mathrm{O} \cdot 2 \mathrm{SiO}_{2} \cdot \mathrm{Al}_{2} \mathrm{O}_{3} \cdot \mathrm{nH}_{2} \mathrm{O}\right)$ of ultrafine size as pretreatment, which were used for the removal of metal ions in the past; electrokinetic measurements 
showed an iso-electric point of solids at a $\mathrm{pH}$ of around 8. The technological importance of zeolites has been attributed to their high surface area in combination with their chemical nature. During the experimental series of continuous-flow separation all the collected samples showed, due to the membrane filtration, $100 \%$ zeolites recovery, hence, showing efficient solid/liquid separation. The metal removal depended just on the amount of adsorbent used. The metal ion (copper) recovery was then investigated with a real mine effluent from Assarel-Medet, Bulgaria, and promising results were obtained [52]. The residual copper in solution was always inside the accepted standards. The copper content in the produced flotation froth approached $6 \%$ by weight. Such a concentration allows economical copper recovery from the froth concentrate.

Figure 6 presents the hybrid process flowsheet used in the economic study, applying the software tool SuperPro Designer (Intelligen Inc., Massachusetts, USA) - presented in the form of tables, a photograph of the lab column is also presented, which had a height of $0.48 \mathrm{~m}$ and an inside diameter of $0.10 \mathrm{~m}$. The cost of the combined process is not the mere addition of the individual process costs: The required membrane surface, which is a major cost factor, is smaller in the hybrid process since flotation has removed the majority of solid particles, and therefore, a smaller membrane area is required to yield the same permeate. It was shown that the capital investment for a $10 \mathrm{~m}^{3} / \mathrm{h}$ plant (the scale-up was based on the obtained lab results) would be of the order of US\$ 1.15 million. The operating costs are about US\$1.76 million per year. The total revenues from water recycling and reuse are US\$ 68,800 per year, without calculating the benefits of copper recovery.

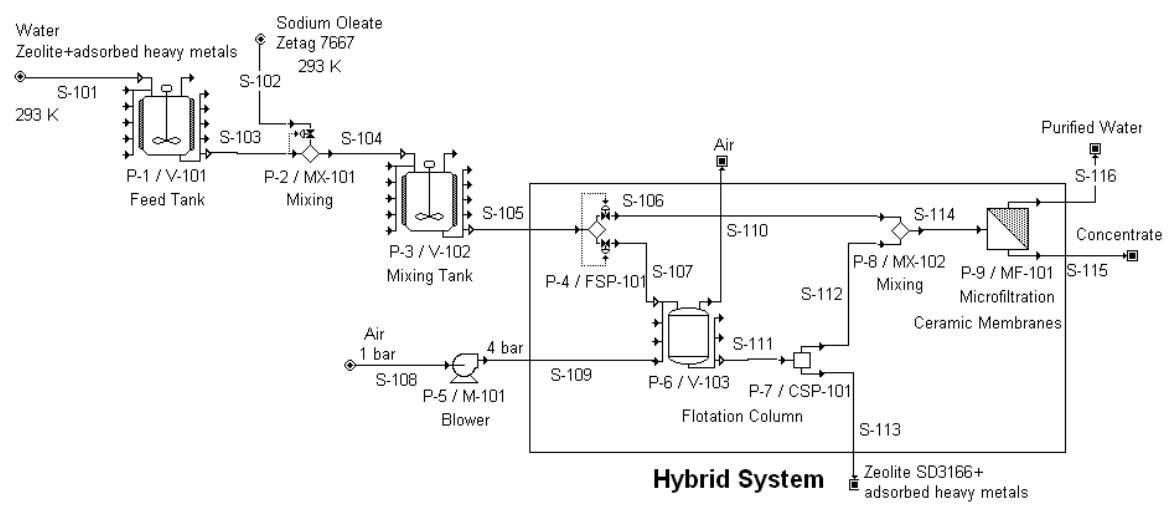

(a)

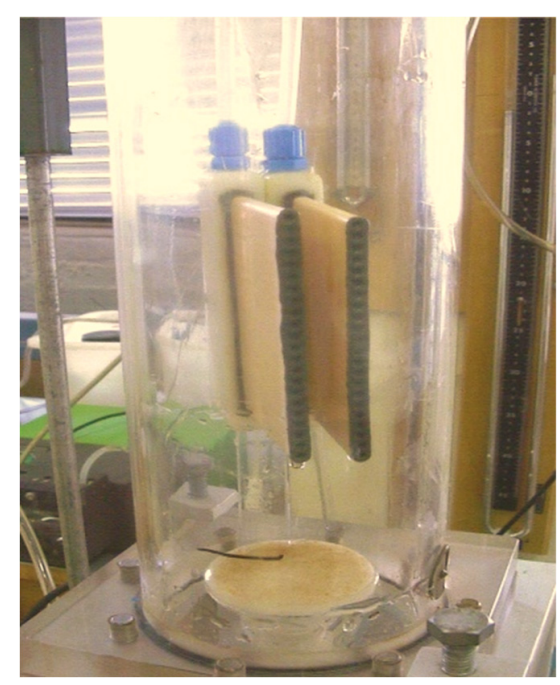

(b)

Figure 6. (a) Flowsheet for the techno-economical study for the hybrid system, applying adsorptive flotation. (b) A close-view photograph of the hybrid cell at the laboratory. Reprinted with permission; copyright Elsevier [34]. 


\section{Green Chemicals May Be a Solution}

Evaluation of the impacts of reagents on safety, health, and the environment (SHE) is crucial for industries, regulatory agencies, and governments; so, an evaluation was developed to provide a holistic assessment of reagents [53]. Glycolipids derived from renewable resources such as carbohydrates, amino acids, and vegetable oils, i.e., biosourced surfactants, were said to be the environmentally friendly alternative to petroleum-based products [54]. Earlier findings implied that some biosurfactants, such as tea saponin, can replace chemosynthetic surfactants in controlling bubble behavior in flotation operation [55]. The hydrodynamics governing the flotation process (the aeration, collection, and separation steps) have been recently investigated [56].

Hence, biosurfactants are chemicals produced by microorganisms, which have both clearly defined hydrophilic and hydrophobic groups. Lychenysin A is a surface-active lipopeptide, which was isolated and characterized (structurally) from Bacillus licheniformis; it was found to compare favorably with other known chemical surface active agents-i.e., capable of reducing the surface tension of water from 72 to $28 \mathrm{mN} / \mathrm{m}$ with a critical micelle concentration as low as $12 \mu \mathrm{M}$ [57]. The name surfactin, being the other biosurfactant tried, refers to a bacterial cyclic lipopeptide, primarily renowned for its exceptional surfactant power, since it lowers the surface tension of water from 72 to $27 \mathrm{mN} / \mathrm{m}$ at a concentration as low as $20 \mu \mathrm{M}$; it was discovered as a biologically active compound in the culture broth of the Bacillus subtilis strain [58]. The above biosurfactants were examined as alternative collectors for adsorptive flotation, as presented in Figure 7. Chromates in the examined $\mathrm{pH}$ range exist mainly in the forms of $\mathrm{HCrO}_{4}{ }^{-}$and $\mathrm{Cr}_{2} \mathrm{O}_{7}{ }^{2-}$ anions, as shown by the aqueous speciation of this toxic metal. Following the respective comparison, it was concluded that surfactin and lychenysin biosurfactants could effectively remove synthetic goethite, $\alpha-\mathrm{FeO}(\mathrm{OH})$, in the $\mathrm{pH}$ range of $4-7$ and presented a superior flotation collector activity in relation to dodecylamine and sodium dodecyl sulfate under the studied experimental conditions. Tightening environmental regulations and increasing awareness of the need to protect ecosystems have effectively resulted in an increased interest in the use of biosurfactants.

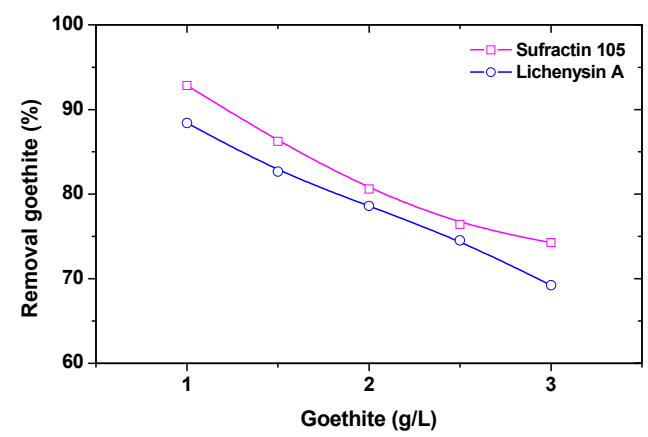

(a)

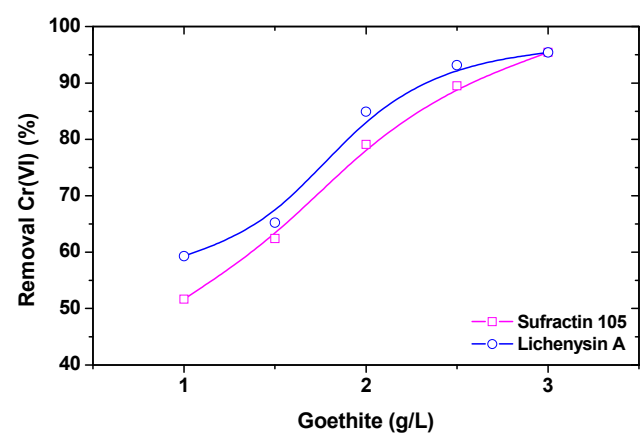

(b)

Figure 7. (a) Separation of goethite (adsorbent) by flotation, using biosurfactants; and (b) separation of chromates by adsorptive flotation, using biosurfactants. Reprinted with permission; copyright Elsevier [59]. 
Rhamnolipids are a class of biosurfactants, which contain rhamnose as the sugar moiety linked to $\beta$-hydroxylated fatty acid chains; Pseudomonas aeruginosa is still the most competent producer of rhamnolipids, but its pathogenicity may cause safety and health concerns during large-scale production and applications [60]. Lipases, produced by organisms of microbial, plant, and animal origin, are acknowledged as relevant biocatalysts for numerous important applications, including biosurfactant production; microbial lipases (i.e., from the marine environment) have attracted far more interest from researchers and industries than lipases from other sources, due both to their specific features and ease of production on a large scale [61-63].

\section{Conclusions}

Flotation with its various techniques is known to be (as also analyzed in the aforementioned) an effective separation process, assisting in the recovery of different materials and, hence, recycling. However, most of the petroleum-based surfactants are ecologically hazardous materials, whereas biosurfactants obtained from natural origins are green surfactants; the latter, following their suitable future development, may be further introduced in the process. Additionally, the use of membranes either together, as a hybrid unit, or downstream would help in contributing toward a better environment.

Author Contributions: This article was written by G.Z.K. and K.A.M. who are the guest editors of this Special Issue "Green Separation and Extraction Processes". G.Z.K. has earlier worked at the Department of Chemistry, Aristotle University of Thessaloniki, Greece.

Funding: This research received no external funding.

Conflicts of Interest: The authors declare no conflict of interest.

\section{References}

1. Zhuo, Q.; Liu, W.; Xu, H.; Sun, X.; Zhang, H.; Liu, W. The effect of collision angle on the collision and adhesion behavior of coal particles and bubbles. Processes 2018, 6, 218. [CrossRef]

2. Wei, G.; Liu, H.; Liu, F.; Zeng, T.; Liu, G.; Zhou, J. Experimental investigation of the decarburization behavior of medical waste incinerator fly ash (MWIFA). Processes 2018, 6, 186. [CrossRef]

3. Schmideder, S.; Kirse, C.; Hofinger, J.; Rollié, S.; Briesen, H. Modeling the separation of microorganisms in bioprocesses by flotation. Processes 2018, 6, 184. [CrossRef]

4. Liu, F.; Liu, H.-Q.; Wei, G.-X.; Zhang, R.; Zeng, T.-T.; Liu, G.-S.; Zhou, J.-H. Characteristics and treatment methods of medical waste incinerator fly ash: A review. Processes 2018, 6, 173. [CrossRef]

5. Kyzas, G.Z.; Matis, K.A. Flotation in water and wastewater treatment. Processes 2018, 6, 116. [CrossRef]

6. Crabtree, E.H.; Vincent, J.D. The early days of froth flotation. In Froth Flotation-50th Anniversary Volume; Fuerstenau, D.W., Ed.; AIMME: New York, NY, USA, 1962; pp. 39-54.

7. Glembotskii, V.A.; Klassen, V.I.; Plaksin, I.N. Flotation; Primary Sources: Moscow, Russia, 1972; p. 399.

8. Hansen, C.A.; Gotaas, H.B. Sewage treatment by flotation. Sewage Works J. 1943, 15, 242-252.

9. Matis, K.A.; Lazaridis, N.K. Flotation techniques in water technology for metals recovery: Dispersed-air vs. dissolved-air flotation. J. Min. Metall. A 2002, 38, 1-27.

10. Peleka, E.N.; Matis, K.A. Water separation processes and sustainability. Ind. Eng. Chem. Res. 2011, 50, 421-430. [CrossRef]

11. King, C.J. From unit operations to separation processes. Sep. Purif. Methods 2000, 29, 233-245. [CrossRef]

12. Trismawati, T.; Wardana, I.N.G.; Hamidi, N.; Sasongko, M.N. Seed oil of Morinda citrifolia L. as a surfactant for deinking flotation. Int. J. Chem. Eng. 2017, 2017, 8962781. [CrossRef]

13. Flores-Campos, R.; Estrada-Ruiz, R.H.; Velarde-Sánchez, E.J. Study of the physicochemical effects on the separation of the non-metallic fraction from printed circuit boards by inverse flotation. Waste Manag. 2017, 69, 400-406. [CrossRef] 
14. Brosseau, C.; Émile, B.; Labelle, M.-A.; Laflamme, É.; Dodd, P.L.; Comeau, Y. Compact secondary treatment train combining a lab-scale moving bed biofilm reactor and enhanced flotation processes. Water Res. 2016, 106, 571-582. [CrossRef] [PubMed]

15. Leong, H.Y.; Ooi, C.W.; Law, C.L.; Julkifle, A.L.; Katsuda, T.; Show, P.L. Integration process for betacyanins extraction from peel and flesh of Hylocereus polyrhizus using liquid biphasic electric flotation system and antioxidant activity evaluation. Sep. Purific. Technol. 2019, 209, 193-201. [CrossRef]

16. Yin, X.; Wang, Y.; Bai, X.; Wang, Y.; Chen, L.; Xiao, C.; Diwu, J.; Du, S.; Chai, Z.; Albrecht-Schmitt, T.E. Rare earth separations by selective borate crystallization. Nat. Commun. 2017, 8, 14438. [CrossRef] [PubMed]

17. Bai, C.; Guo, M.; Liu, Z.; Wu, Z.; Li, Q. A novel method for removing of boron from aqueous solution using sodium dodecyl benzene sulfonate and D-mannitol as the collector. Desalination 2018, 431, 47-55. [CrossRef]

18. Deliyanni, E.A.; Kyzas, G.Z.; Matis, K.A. Various flotation techniques for metal ions removal. J. Mol. Liq. 2017, 225, 260-264. [CrossRef]

19. Peleka, E.N.; Gallios, G.P.; Matis, K.A. A perspective on flotation: A review. J. Chem. Tech. Biotechnol. 2018, 93, 615-623. [CrossRef]

20. Kyzas, G.Z.; Lazaridis, N.K.; Matis, K.A. Flotation: Recent innovations in an interesting and effective separation process. In Advanced Low-Cost Separation Techniques in Interface Science; Kyzas, G.Z., Mitropoulos, A.C., Eds.; Elsevier: Amsterdam, The Netherlands, 2019; in press.

21. Hayat, M.B.; Alagha, L.; Sannan, S.M. Flotation behavior of complex sulphide ores in the presence of biodegradable polymeric depressants. Int. J. Polymer Sci. 2017, 2017, 4835842. [CrossRef]

22. Kydros, K.A.; Gallios, G.P.; Matis, K.A. Modification of pyrite and sphalerite flotation by dextrin. Sep. Sci. Technol. 1994, 29, 2263-2275. [CrossRef]

23. Laitinen, O.; Hartmann, R.; Sirviö, J.A.; Liimatainen, H.; Rudolph, M.; Ämmälä, A.; Illikainen, M. Alkyl aminated nanocelluloses in selective flotation of aluminium oxide and quartz. Chem. Eng. Sci. 2016, 144, 260-266. [CrossRef]

24. Hartmann, R.; Kinnunen, P.; Illikainen, M. Cellulose-mineral interactions based on the DLVO theory and their correlation with flotability. Miner. Eng. 2018, 122, 44-52. [CrossRef]

25. Kyzas, G.Z.; Matis, K.A. Methods of arsenic wastes recycling: Focus on flotation. J. Mol. Liq. 2016, $214,37-45$. [CrossRef]

26. Williams, C.; Peng, Y.; Dunne, R. Eucalyptus oils as green collectors in gold flotation. Miner. Eng. 2013, 42, 62-67. [CrossRef]

27. Liu, G.; Liu, J.; Huang, Y.; Yang, X.; Zhong, H. New advances in the understanding and development of flotation collectors: A Chinese experience. Miner. Eng. 2018, 118, 78-86. [CrossRef]

28. Quintanar, C.; Palominos, M. Rejection of pyrite: Challenges and sustainable chemical solutions. In Proceedings of the 27th International Mineral Processing Congress, Santiago, Chile, 24 October 2014.

29. Barbery, G. Complex sulphide ores: Processing options, In Mineral. Processing at a Crossroads-Problems and Prospects; Wills, B.A., Barley, R.W., Eds.; Martinus Nijhoff: Dordrecht, The Netherlands, 1986; pp. 157-194.

30. Espiritu, E.R.L.; Waters, K.E. Flotation studies of monazite and dolomite. Miner. Eng. 2018, 116, $101-106$. [CrossRef]

31. Zhao, Y.-C.; Zouboulis, A.I.; Matis, K.A. Removal of molybdate and arsenate from aqueous solutions by flotation. Sep. Sci. Tech. 1996, 31, 769-785. [CrossRef]

32. Zhao, Y.-C.; Zouboulis, A.I.; Matis, K.A. Flotation of molybdate oxyanions in dilute solutions. Part II. Selective separation from phosphates, arsenates and silicates. Hydrometallurgy 1996, 43, 155-167. [CrossRef]

33. Zoubouls, A.I.; Matis, K.A. Removal of cadmium from dilute solutions by flotation. Water Sci. Technol. 1995, 31, 315-326. [CrossRef]

34. Matis, K.A.; Lazaridis, N.K.; Zouboulis, A.I.; Gallios, G.P.; Mavrov, V. A hybrid flotation-microfiltration process for metal ions recovery. J. Membr. Sci. 2005, 247, 29-35. [CrossRef]

35. Ngah, W.S.W.; Isa, I.M. Comparison study of copper ion adsorption on chitosan, dowex A-1, and Zerolit 225. J. Appl. Polym. Sci. 1998, 67, 1067-1070. [CrossRef]

36. Rubin, A.J.; Johnson, J.D.; Lamb, J.C., III. Comparison of variables in ion and precipitate flotation. Ind. Eng. Chem. Proc. Des. Develop. 1966, 5, 368-375. [CrossRef] 
37. Zouboulis, A.I.; Matis, K.A.; Stalidis, G.A. Parameters influencing flotation in the removal of metal ions. Int. J. Envir. Stud. (Sect. B) 1990, 35, 183-196. [CrossRef]

38. Matis, K.A.; Papadoyannis, I.N.; Zouboulis, A.I. Separation of germanium and arsenic from solutions by flotation. Int. J. Miner. Process. 1987, 21, 83-92. [CrossRef]

39. Zouboulis, A.I.; Matis, K.A. Metal ion flotation in hydrometallurgy; the case of Ge recovery. In Flotation Science and Engineering; Matis, K.A., Ed.; Dekker: New York, NY, USA, 1995; pp. 517-550.

40. Kandasamy, G.; Shaleh, S.R.M. Flotation removal of the microalga Nannochloropsis sp. using Moringa protein-oil emulsion: A novel green approach. Bioresource Technol. 2018, 247, 327-331. [CrossRef] [PubMed]

41. Alhatttab, M.; Brooks, M.S.-L. Dispersed air flotation and foam fractionation for the recovery of microalgae in the production of biodiesel. Sep. Sci. Technol. 2017, 52, 2002-2016. [CrossRef]

42. Xu, K.; Zou, X.; Wen, H.; Xue, Y.; Zhao, S.; Li, Y. Buoy-bead flotation harvesting of the microalgae Chlorella vulgaris using surface-layered polymeric microspheres: A novel approach. Bioresour. Technol. 2018, 267, 341-346. [CrossRef] [PubMed]

43. Teixeira, M.R.; Camacho, F.P.; Sousa, V.S.; Bergamasco, R. Green technologies for cyanobacteria and natural organic matter water treatment using natural based products. J. Clean. Prod. 2017, 162, 484-490. [CrossRef]

44. Matis, K.A.; Zouboulis, A.I.; Lazaridis, N.K. Removal and recovery of metals from dilute solutions: Applications of flotation techniques. In Mineral. Processing and the Environment; Gallios, G.P., Matis, K.A., Eds.; Kluwer: Dordrecht, The Netherland, 1998; pp. 165-196.

45. Kyzas, G.Z.; Matis, K.A. Flotation of biological materials. Processes 2014, 2, 293-310. [CrossRef]

46. Matis, K.A.; Zouboulis, A.I. Flotation of cadmium-loaded biomass. Biotechnol. Bioeng. 1994, 44, 354-360. [CrossRef] [PubMed]

47. Zouboulis, A.I.; Lazaridis, N.K.; Matis, K.A. Removal of toxic metal ions from aqueous systems by biosorptive flotation. J. Chem. Tech. Biotechnol. 2002, 77, 958-964. [CrossRef]

48. Matis, K.A. Treatment of industrial liquid wastes by electroflotatio. Water Pollut. Control. 1980, 79, $136-142$.

49. Ketkar, D.R.; Mallikarjunan, R.; Venkatachalam, S. Electroflotation of quartz fines. Int. J. Miner. Process. 1991, 31, 127-138. [CrossRef]

50. Matis, K.A.; Peleka, E.N. Alternative flotation techniques for wastewater treatment: Focus on electroflotation. Sep. Sci. Technol. 2010, 45, 2465-2474. [CrossRef]

51. Peleka, E.N.; Matis, K.A. Bioremoval of metal ion and water treatment in a hybrid unit. Sep. Sci. Technol. 2009, 44, 3597-3614. [CrossRef]

52. Peleka, E.N.; Fanidou, M.M.; Mavros, P.P.; Matis, K.A. A hybrid flotation-microfiltration cell for S/L separation: Operational characteristics. Desalination 2006, 194, 135-145. [CrossRef]

53. Shen, Y.; Lo, C.; Nagaraj, D.R.; Farinato, R.; Essenfeld, A.; Somasundaran, P. Development of Greeness Index as an evaluation tool to assess reagents: Evaluation based on SDS (Safety Data Sheet) information. Miner. Eng. 2016, 94, 1-9. [CrossRef]

54. Sekhar, K.P.C.; Nayak, R.R. Nonionic glycolipids for chromium flotation- and emulsion-based bioactive release. Langmuir 2018, 34, 14347-14357. [CrossRef] [PubMed]

55. Wang, H.; Yang, J.; Lei, S.; Wang, X. Comparing the effect of biosurfactant and chemical surfactant on bubble hydrodynamics in a flotation column. Water Sci. Technol. 2013, 68, 783-790. [CrossRef] [PubMed]

56. Peleka, E.N.; Matis, K.A. Hydrodynamic aspects of flotation separation. Open Chem. 2016, 14, $132-139$. [CrossRef]

57. Yakimov, M.M.; Giulano, L.; Timmis, K.N.; Golyshin, P.N. Recombinant acylheptapeptide lichenysin: High level of production by Bacillus subtilis cells. J. Mol. Microbiol. Biotechnol. 2000, 2, 217-224. [PubMed]

58. Peypoux, F.; Bonmatin, J.M.; Wallach, J. Recent trends in the biochemistry of surfactin. Appl. Microbiol. Biotechnol. 1999, 52, 553-563. [CrossRef]

59. Zouboulis, A.I.; Matis, K.A.; Lazaridis, N.K.; Golyshin, P.N. The use of biosurfactants in flotation: Application for the removal of metal ions. Minerals Eng. 2003, 16, 1231-1236. [CrossRef]

60. Chong, H.; Li, Q. Microbial production of rhamnolipids:opportunities, challenges and strategies. Microb. Cell Fact. 2017, 16, 137. [CrossRef]

61. Navvabi, A.; Razzaghi, M.; Fernandes, P.; Karami, L.; Homaei, A. Novel lipases discovery specifically from marine organisms for industrial production and practical applications. Process. Biochem. 2018, 70, 61-70. [CrossRef] 
62. Papadopoulos, A.N.; Militz, H.; Pfeffer, A. The biological behaviours of pine wood chemically modified with linear chain carboxylic acid anhydrides against soft rot fungi. Int. Biodeter. Biodegrad. 2010, 64, 409-412. [CrossRef]

63. Papadopoulos, A.N.; Duquesnoy, P.; Cragg, S.M.; Pitman, A.J. The resistance of wood modified with linear chain carboxylic acid anhydrides to attack by the marine wood borer Limnoria quadripunctata Hothius. Int. Biodeter. Biodegrad. 2008, 61, 199-202. [CrossRef] 